\title{
ДУХОВНО-МЕНТАЛЬНІ ЗАСАДИ «ЧУЖИНСТВА» В ХУДОЖНІЙ ІНТЕРПРЕТАЦІЇ ВАЛЕРІЯ ШЕВЧУКА
}

\begin{abstract}
Л.О. Донченко
Кінець ХХ століття означився спалахом народних рухів, спрямованих на національне самоствердження. Крах радянської імперії змінив світовий ідеологічний устрій. Поневолені народи високо підняли знамена незалежності, щоб світ помітив їх унікальність і справжню вартість. Відомо, що цю ідею обгрунтував ще у XVIII столітті німецький поет-романтик і філософ Готфрід Гердер. Заперечуючи вищість одного народу щодо іншого, він наголошував, що кожний народ має власний Volksgeist-національний дух, сукупність звичок і манер, спосіб почування, цінованих тільки за те, що вони свої. Культурне життя спирається на традиції, що ïx витворив колективний історичний досвід, який поділяють лише члени цієї групи. Тому сповна не можна зрозуміти скандинавські саги, не переживши бурі у Півничному океані. Потерпаючи під час «шторму», людина схильна сподіватися на підтримку «своїх».

Цю думку підкреслює Норман Манеа в роздумах про чужинство: «I хоча людину вчать любити ближнього, у неї, здається, не виходить любити ближнього так, як вона любить себе, чи любити чужого як ближнього. Чужого завжди сприймали як іншого, часто як виклик, навіть як явну загрозу для витворених традиційним способом життя спільних общинних звичаїв і національних символів. Існування чужинця завжди передбачає порівняння, переоцінку та потенційне суперництво» [8, с. 109].

Ісайя Берлін, розглядаючи націоналізм як спосіб вираження синтезу певних станів свідомості, наголошував: «Сильнішим його аргументом, який доводить необхідність мати певні переконання, діяти певним способом, служити певним цілям лише тому, що згадані цілі, переконання, способи поведінки і життя - наші. Це значить, що всі ті правила, доктри-
\end{abstract}

Актуальні проблеми духовності

(Відп. ред.: Я.В. Шрамко)

Кривий Ріг (2005), 251-257 
ни й принципи слід виконувати не тому, що вони ведуть до добра, щастя, справедливості і свободи, не тому, що вони встановлені Богом. . ., і не тому що вони самі по собі слушні і справедливі, самі в собі знаходять наснагу. .., ні, ними треба керуватися лише тому, що це вартості моєї групи. .. » [3, c. 102$]$.

В. Шевчук належить до тих письменників, які відверто маніфестують свою приналежність до українства, і в своїх статтях він прямо пише про симпатії до поляків і висловлює критичне ставлення до росіян. Очевидно, першому сприяло походження матері письменника, яка мала польський родовід та спогади дитинства про житомирських інтелігентів, які «найменше піддавалися русифікації [10, с.55], це була група «вірою таки твердо католицька, але етнічно ближча до українства ніж до польськості» $[10$, c. 55$]$.

Орієнтація на європейський спосіб мислення передбачає заперечення окремих сторін російської ментальності. Щоб визначити міру несприйняття і навіть іронічного ставлення автора до цінностей ближнього північного сусіда, необхідно звернутись до роздумів російських і українських філософів, спрямованих на дослідження власного «національного».

Аналізуючи субстанційні ознаки духовного складу українців, Михайло Грушевський зараховує останніх до західної моделі культури (із вкрапленнями певних орієнтальних впливів), що, на його думку, може служити основою для здобуття українським народом державності і набуття суверенності. Українську ментальність характеризує типологічна спорідненість із західноєвропейською. У цьому сенсі українськими «народними прикметами» для Грушевського є певні риси, які характеризуються «високим розвитком гідності своєї, пошануванням гідності чужої, любові до певних, усталених зверхніх форм, „законних речей“, етикету, добрих манер, любов'ю до чистоти, порядку, красоти життя, прив'язанням до культурних і громадських вартостей життя і т. ін. Се все прикмети, які роблять українця дуже близьким по духу, по характеру до західноєвропейської стихії-де в чім до германської, з їі солідністю, діловитістю, любов'ю до комфорту, порядку, чистоти, достатності, до рівноваги і стоїцизму, а в іншім до романської-наприклад оцим потягом до форми, елеганції, бажанням ввести в усе красоту, освітити нею всяку сферу життя взагалі світлим і ясним, радісним поглядом на життя» [6, с. 147-148].

Суспільна психіка українців теоретично осмислювалась В.Липинським. Він розцінював як деструктивні фактори в історичному бутті, 3 одного боку, - нігілістичне ставлення і потяг до нищення набутих культурних цінностей та ієрархії авторитетів, а з другого боку, примітивність пропонованої суспільної альтернативи, яка не йде далі гіпертрофованого індивідуалізму, анархізму й екзистенціального виміру свідомості, відірваної від «коренів» [7, с. 66]. 
Початком російського філософського дискурсу можна вважати «філософічний лист» Петра Чаадаєва, в якому він експліцитно поставив питання про неоригінальність російської національної культури.

«Дело в том, что мы никогда не шли вместе с другими народами, мы не принадлежим ни к одному из известных семейств человеческого рода, ни к Западу, ни к Востоку, и не имеем традиций ни того, ни другого...

Все - словно на перепутье... Ни у кого нет определенного круга действия, нет ни на что добрых навыков, ни для чего нет твердых правил, нет даже и домашнего очага, ничего такого, чтобы привязывало, что пробуждало бы ваши симпатии, вашу любовь, ничего устойчивого, ничего постоянного; все исчезает, все течет не оставляя следов ни вовне, ни в вас. В домах наших мы как будто в лагере: в семьях мы имеем вид пришельцев: в городах мы похожи на кочевников, хуже кочевников, пасущих стада в наших степях, ибо те более привязанные к своим пустыням, нежели мык своим городам...» $[9$, с. $25-26]$.

Інтерес до національного виявляла російська філософія початку століття як складова парадигми ідеалістичної традиції в західній думці, акцентуючи увагу на містичному началі російської душі. Була підхоплена ідея $\Phi$. Ніцше про перевагу в російській загадковій душі діонісійського стихійного начала на відміну від аполонівського гармонійного західноєвропейського мислення. Проблема подолання дуалізму і витворення синтезу цих начал тривожила Д. Мережковського, В. Соловйова, М. Булгакова. Зокрема В. Соловйов, наголошуючи на функції містичного елемента в російській ментальності, не погоджувався з Шопенгауером і Гартманом в їх міркуваннях про сліпу руйнівну силу безсвідомого й вбачав у ньому вищу орієнтацію для розуму.

Влучна характеристика російської ментальності подана в статті Миколи Бердяєва «Русская идея»: «Два противоположных начала легли в основу формации русской души: природная, языческая, дионисическая стихия и аскетически-монашеское православие. Можно открыть противоположные свойства в русском народе: деспотизм, гипертрофия государства и вольность, жестокость, склонность к насилию и доброта, человечность, мягкость, обрядоверие и искание правды, индивидуализм, обостренное сознание личности и безличный коллективизм, национализм, самохвальство и универсализм, всечеловечность, эсхатологически-мессианская религиозность и внешнее благочестие, искание Бога: смирение и наглость, рабство и бунт» $[2$, с. 77$]$.

У своїй відомій промові (прочитаній у Римі) «Русский национальный характер» філософ Б.П.Вишеславцев також наголошував на нестійких рисах: «Мы и сами себя не понимаем, и, пожалуй непонятность, иррациональность поступков и решений составляют некоторую черту нашего характера... Нужно сказать, что область подсознательного в душе русского 
человека занимает исключительное место. Национальная скромность, самокритика и самоосуждения составляют нашу несомненную черту» $[4$, с.112]. Філософ порівнює італійську і російську пристрасність. В роздумах про своєрідність російського національного характеру А.Бєлий теж використовує принцип порівняння: «Говорят, что широкая славянская натура чуждается тех рамок, в которых с таким удобством уживается натура немца. Говорят, что славяне глубже французов. Глубина и ширина сочетается в нас, русских...ГЛубина отрывает от жизни, ширина сжигает душу и беспочвенный, но широкий и глубокий русский интеллигент оказывается с отчаянием в душе и с опушенными руками пьяницы после запоя... У нас нет повседневности, у нас везде святое святых» [1, с. 325].

Російська ментальність стала предметом культурологічного дискурсу Г. Гачева. Він пропонує теорію «космопсихологосу»: «подобно тому, как каждое существо есть троичное единство: тело, душа, дух - так и национальная целостность есть единство природы (космос), национального характера народа (Психея) и склада мышления (Логос)» [5, с. 263]. Згідно зі своєю теорією він виводить закономірність руху російського буття: «Несоответствие шага Пространства и шага Времени - это вечная трагедия как России и русского социума, который сказывается и в русском логосе. В нем естественен задний ум. . . Разные темпоритмы. Россия - это рассеянное бытие, разреженное пространство...» [5, с. 27]. Філософ вважав, що реальність впливає на мислення, тому на (відміну від Заходу, в російському Логосі «не вполне работает ... рассудочная логика, а образ работает потому, что он может перепрыгнуть через знание, в метафоре переносе» [5, с. 27-28].

Отже, можемо констатувати, що дослідники російської ментальності в пошуках оригінальних рис національної ідентичності йшли шляхом зіставлення її з певними моделями фундаментальних ментальних структур, що притаманні європейським народам.

Цей принцип порівняння обирає і В.Шевчук. Вельми репрезентативною у цьому відношенні $\epsilon$ його повість «У пащу Дракона», яка $\epsilon$ спеціальним об'єктом нашого аналізу.

В названому творі представлено парадигматичну політичну модель українського і російського національного характерів. Причому принципова схема українського національного характеру в своїй особі побудована від противного: письменник неявно конструює тип української ідентичності, вдаючись до послідовного «закреслення» неприйнятних для нього рис в російській ідентичності. Ще однією особливістю повісті є те, що, незважаючи на часові рамки зображуваного - першу половину XVII ст., національно забарвлені сюжети великою мірою ціннісно відградуйовуються відповідно до поширених ідеологічних уявлень буденної свідомості сучасності. Тобто, в повісті «У пащу Дракона» «національне» дещо позірно 
історичне. Адже одягнуті в старосвітські шати персонажі з однієї (української) і другої (російської) сторін часто розмислюють і діють відповідно до політичних й естетичних уявлень та приписів постперебудовного і пострадянського часу.

Загалом, в цьому творі добре простежується прагнення письменника показати дві онтологічно протилежні моделі національного характеру: українську - демократичну, західного зразка та російську - авторитарну, східну, автаркійну. Відповідно до ідеологічної мети та художньо-естетичної спрямованості повісті, В.Шевчук активно експлуатує сучасні ідеологічні міфи про Росію й підкориговує історичні факти, накидаючи при цьому на росіян аж занадто багато моральних вад і дивацтв. Якщо абстрагуватися від подібних «витрат жанру», то за художніми перебільшеннями можна помітити методологічні структурні складники авторської концепції «національного».

При цьому з'ясовується, що ідентичність українського національного характеру постає в творі великою мірою у «знятому» вигляді. А самевона проявляється як певне ціннісне ставлення відношення до маніфестацій чужої культури та національної ідентичності. Звідси випливає неявно постульована теза про неприйнятність для українського національного характеру авторитарної моделі совісті, сліпого релігійного фанатизму, масових психозів і пароксизмів чуттєвості, агресивних імперських амбіцій, тяжіння до самодостатньої замкненості культури в архаїчній формі.

Фактор конфесійної тотожності українців та росіян набуває у повісті значення не інтегруючого, а диференціюючого чинника. Останнє досягається шляхом зображення Московської держави першої половини XVII ст. як країни «нечестивої», «царства Дракона», або, «імперії зла». 3 другого боку, письменник розводить православних по обидва боки московськопольського (українського) кордону, вдаючись до методики підключення авторитету автентичних джерел духовної культури українського народу - православної традиції давньої Київської держави: єрусалимський патріарх, який репрезентує духовне наступництво православної церкви Візантії (від якої прийняло християнство давньоруське суспільство) і в почеті якого є українці-засуджує порядки московитів, котрі суперечать ортодоксальному православ'ю.

Окрім окреслення рис національної ідентичності українців таким ускладненим, кружним шляхом, у повісті «У пащу Дракона» артикульовано заявляють про себе і репрезентанти українського духовного «простору». В центрі роздумів, поривань і вчинків двох українських мандрівників, доля яких закинула у Велике Московське князівство, постійно перебуває ідея збереження і творення Храму, який виступає символом справжньої національної ідентичності. Ніби наперед прозираючи невдалі спроби утвердження української державності після 1654 р. та в 1918 р., фатальну роль 
у чому відіграв російський політичний фактор, а також вгадуючи важке становлення української держави сучасності, герої твору наголошують на негативах українського характеру: політичній наївності та інфантильності, проявах зневіри у власних силах, недостатньо твердій волі задля досягнення стратегічних цілей. «Біда наша в тому, - твердить один із персонажів повісті, - що не самі хочемо будувати свій Храм, а сподіваємося, що його збудує нам хтось. Шукаємо любові, а знаходимо зненависть, шукаємо брата, а знаходимо ворога. Оце і є віковічне наше спитування, але чи від нього стаємо чисті духом?» [11, с.53]. Загалом повість «У пащу Дракона» можна трактувати і як своєрідне застереження проти повторення давніх помилок, коли український народ не зміг себе реалізувати як суверенна нація внаслідок того, що опинився в занадто міцних «обіймах» свого східного сусіда. Це застереження вкладено в уста головного героя твору, який відправився в країну московського царя з надією відбудувати власний Храм, пройшов по шляху суворих випробувань і важкого душевного сум'яття (Чи є Бог в «царстві Дракона»? Чи не облудний голос покликав у дорогу?), а під трагічний кінець своєї місії зрозумів її істинне призначення: «не відбудувати на рідній землі Храм, а перепинити Драконові дорогу» $[11$, с. 75$]$.

Ясна річ, що практично в кожному творі В.Шевчука можна віднайти принаймні «інверсійний слід» народної культури, або, приміром, «національне» у формі неявно вираженої ментальної установки. Проте ми не ставили собі за мету «інвентаризувати» всі подібні прояви чи вивести якийсь середній показник представленості в творах засадних елементів національної ідентичності і національного характеру. Перед нами стояло, гадаємо, методологічно більш щільне завдання - атрибутувати маніфестації «національного» в художніх текстах письменника за такими двома основними критеріями:

По-перше, підійти до розгляду національно означених компонентів тексту як формальних засобів, метамови, на які спирається автор задля досягнення певних художньо-естетичних цілей, - причому спеціально не пов'язаних із «національною» тематикою. В результаті виявилося, що народні архетипові уявлення, традиційні риси українського характеру, ментально-психологічні «коди» й установки соціальної поведінки українців складають пружний «технічний» каркас літературного дискурсу В.Шевчука. Інакше кажучи, це імплантовані в текстуальну тканину «знакові» спрямовуючі, які «мовчазно промовляють» самі за себе й упізнаються, однак не коригують основне русло сюжетної оповіді, наприклад, в значенні її спеціального етнографування. Саме це, на наш погляд, створює в творах письменника своєрідний чар «національного».

По-друге, наше завдання полягало у виявленні авторської рефлексії над «національним». Як засвідчив аналіз особливо репрезентативної з цієї 
точки зору повісті «У пащу Дракона», письменник розглянув національний характер українців у парній опозиції до російського національного характеру. Оскільки тема «національного» освітлена в повісті через контекстний фільтр пошуків національної свободи, що утверджує національну ідентичність народу, то другий член цієї опозиції- російський національний характер, відіграв роль негативного фону, на якому окреслилися основоположні риси українського національного характеру. Звідси, гадаємо, надмірна доля авторського суб'єктивізму й елементи шаржу в описах населення Московської держави першої половини XVII ст.

\section{1 Бібліографія}

[1] Бельй $A$. Символизм как миропонимание // Поэтические течения в русской литературе конца XIX - начала XX века: Литературные манифесты и художественная практика. - М., 1998.-C. 69-75.

[2] Бердяев H. Русская идея // Вопросы философии. - 1990. - №1.C. $76-77$.

[3] Берлін I. Націоналізм: знехтувана сила // Сучасність. - 1993.№3. - C. 95-111.

[4] Вышеславцев Б. Русский национальный характер // Вопросы философии. -1995 . - №6. - С. 110-113.

[5] Гачев Г. Национальные образы мира.-M., 1988.

[6] Грушевсъкий $M$. Хто такі українці і чого вони хочуть. - Київ, 1991.

[7] Липинсъкий В. Хам і Яфет: з приводу десятих роковин 16-29 квітня 1918 р. // Сучасність. - 1992. - №6. - С. 66.

[8] Манеа Н. Про чужинство // Сучасність. - 1993. - No 7. - C. 109-114.

[9] Чаадаев П. Философические письма // Чаадаев П. Избранные сочинения и письма. - М., 1991. - С. 22-134.

[10] Шевчук В. Сад житейських думок, трудів і почуттів // Шевчук В. Стежка в траві. - Харків, 1994.- С. 49-78.

[11] Шевчук В. У пащу дракона // Сучасність. - 1994. - №3.- С. 24-75. 